\title{
RADIKALISME ISLAM SEBAGAI PROBLEM BAGI BANGSA INDONESIA DI MASA KONTEMPORER
}

\section{ISLAMIC RADICALISM AS A PROBLEM FOR THE INDONESIAN NATION IN CONTEMPORARY ERA}

\author{
Bani Syarif Maula \\ IAIN Purwokerto
}

banisyarifm@gmail.com

\begin{abstract}
ABSTRAK:Sudah sejak lama Islam Indonesia dikenal dunia sebagai Islam yang ramah dan damai serta toleran dan akomodatif. Namun demikian, runtuhnya rezim otoriter Soeharto menjadi masa transisi yang telah membuka pintu kebebasan seluas-luasnya sehingga ideologi yang berasal dari luar dapat masuk dengan leluasa. Masa transisi tersebut pada akhirnya menjadi tantangan bangsa Indonesia tersendiri. Tantangan tersebut bersumber dari tiga masalah besar, yaitu: pertama adalah adanya kelompok masyarakat yang ingin mengubah konsensus nasional, yaitu Pancasila, UUD 1945, NKRI, dan Bhinneka Tunggal lka; kedua adalah klaim kebenaran Islam sepihak yang marak di tengah-tengah muslim perkotaan karena pengaruh faham salafi/wahabi; dan ketiga adalah kelompok Islam mayoritas yang cenderung diam (silent majority) atas tantangan tersebut. Dua isu pertama dipengaruhi oleh ideologi Islam transnasional dengan pandangan radikal yang memaksakan keyakinannya kepada semua muslim di Indonesia. Sedangkan isu terakhir berasal dari umat Islam mayoritas yang cenderung menikmati alam demokrasi selepas pemerintahan Soeharto. Karena itulah ideologi Islam radikal dapat berkembang di Indonesia. Untuk mengatasi hal tersebut perlu upaya untuk melawan radikalisme Islam tersebut, yaitu dengan bersuara menyampaikan gagasan Islam yang toleran dan inklusif, melakukan reinterpretasi ajaran Islam dengan tajdid dan ijtihad, juga melalui dunia pendidikan yang menekankan aspek-aspek kesadaran multikultural dan kesadaran umat Islam sebagai bagian dari world citizenship.
\end{abstract}

Kata kunci: radikalisme ${ }^{1}$, fundamentalisme ${ }^{2}$, ideologi Islamisme ${ }^{3}$, Indonesia ${ }^{4}$

Abstract: Indonesian Islam has lengthy been known by the arena as a pleasant and peaceful Islam that is tolerant and accommodating. Nevertheless, the fall apart of Suharto's authoritarian regime became a period of transition that has opened the doorways of freedom widest in order that ideology originating from the outdoor can enter freely. The transition duration eventually becomes the task of Indonesia's own nation. The venture is sourced from three important problems: first is the existence of a community that desires to exchange the country consensus, specifically Pancasila, Constitution 1945, the unitary state form of Republic of Indonesia, and Unity in Diversity; The second is a claim of a unilateral Islamic truth that is lively amid city Muslims because of the impact of the salafi / wahabi; And third is the Islamic institution majority that has tendency to be silent majority for the challenge. Two problems have been influenced through transnational Islamic ideology with a thorough view that imposed its belief in all Muslims in Indonesia. While the last trouble comes from Muslim majority tend to enjoy the realm of democracy after Suharto's resign. Therefore, radical Islamic ideology can thrive in Indonesia. In order to overcome this, it is miles necessary to fight the Islamic radicalism, voicing the idea of tolerant and inclusiving Islam, reinterpreting Islamic teachings with Tajdid and litihad, emphasizing aspects of multicultural recognition through the world of education and knowing of Muslims as part of international citizenship.

Keywords: radicalism ${ }^{1}$, fundamentalism ${ }^{2}$, Islamism ideology ${ }^{3}$, Indonesia ${ }^{4}$ 


\section{A. PENDAHULUAN}

Islam Indonesia dikenal dunia sebagai Islam yang ramah dan damai, karena memang Islam menyebar kse Indonesia dilakukan secara damai, dan berkembang dengan pesat secara damai pula. Hal ini mencerminkan adanya sinergi antara Islam sebagai sebuah agama dunia dengan budaya lokal Indonesia yang ramah. Islam dipercaya oleh umatnya sebagai agama rahmatan lil 'ālamīn (rahmat bagi sekalian alam), termasuk memberi rahmat bagi bangsa Indonesia yang majemuk (Bhinneka Tunggal Ika). Namun, selama beberapa dekade terakhir, fenomena kekerasan yang mengatasnamakan agama dan etnis meningkat dan terasa cukup mengganggu kedamaian yang sudah sekian lama tercipta. Konflik Poso, Ambon, bom-bom teroris, kekerasan etnis di Kalimantan, perusakan tempat ibadah minoritas, termasuk kekerasan terhadap jamaah Ahmadiyah dan HKBP adalah kasus-kasus yang bertentangan dengan kepercayaan umat Islam sendiri bahwa Islam adalah agama rahmat dan Indonesia yang majemuk merupakan bagian dari penyebaran rahmat tersebut. Peningkatan konstelasi kekerasan ini menimbulkan tanda tanya tentang sikap keberagamaan sebagian umat Islam yang meyakini bahwa agama mereka merupakan agama pemberi rahmat, dan juga kondisi ini mempertanyakan sikap mereka terhadap kemajemukan bangsa atau mulitkulturalisme, serta terhadap demokratisasi dan modernisasi.

Tantangan bangsa Indonesia belakangan ini kian besar. Setidaknya ada tiga masalah besar yang tengah kita hadapi. Pertama, keberadaan sekelompok kecil masyarakat yang ingin mengubah konsensus nasional, yaitu Pancasila, UUD 1945, NKRI, dan Bhinneka Tunggal Ika. Masalah kedua adalah klaim kebenaran Islam sepihak yang marak di tengah-tengah muslim perkotaan. Sebagian kecil umat Islamyang biasa disebut "salafi”" - menganggap gagasan dan praktik keberislaman merekalah yang benar, sementara di luar kelompok mereka adalah salah, sesat, kafir, musyrik, dan lain-lain. Masalah ketiga adalah kalangan Islam mayoritas yang cenderung diam (silent majority). Meskipun kelompok yang menginginkan penggantian Pancasila sebagai ideologi negara jumlahnya tidak signifikan, namun karena silent majority yang hanya memilih 'diam' dan tidak bersuara 'melawan' dan bersikap tak acuh, pengaruh propaganda khilafah pun meluas. 
Dua isu pertama di atas dipengaruhi oleh ideologi Islam transnasional. Ideologi tersebut memengaruhi sikap dan pandangan sebagian kecil masyarakat Muslim Indonesia terhadap Pancasila dan NKRI sebagai ideologi dan bentuk negara. Selain ajaran politik, ideologi Islam transnasional juga membawa ajaran salafi/wahabi yang sangat mudah menyalahkan dan mengkafirkan orang lain yang berbeda pandangan. Indonesia memang semakin terancam oleh sektarianisme yang disokong tafsir radikal atas nama agama. Dengan keyakinan dan pemahaman radikal tersebut, para pengusung Islam Politik ingin memaksakan pandangan dan keyakinannya kepada semua muslim di Indonesia. Jika tidak mungkin dilakukan, maka mereka merasa berkewajiban untuk mengambil alih kekuasaan dengan cara apapun, sehingga bisa menerapkan sistem pemerintahan yang mereka anggap paling benar menurut Islam. Sedangkan isu terakhir berasal dari umat Islam mayoritas yang cenderung menikmati alam demokrasi selepas pemerintahan Soeharto. Sikap 'terlena' inilah yang menyebabkan berkembangnya ideologi transnasional dan ajaran salafi yang menolak hal-hal yang berasal dari budaya asli bangsa Indonesia karena dianggap bukan berasal dari Islam.

Sikap penolakan terhadap hal-hal baru yang berasal dari luar Islam tersebutdisertai dengan tindakan-tindakan radikal—seringkali dikaitkan dengan isu fundamentalisme dan radikalisme dalam Islam. Tuduhan terhadap Islam yang tidak hanya membawa misi perdamaian, tetapi juga misi kekerasan sulit untuk ditolak manakala kita menyaksikan bahwa agama seringkali digunakan sebagai landasan ideologis dan pembenaran simbolis bagi tindak kekerasan yang dilakukan sebagian umatnya. Karena itulah, fakta-fakta maraknya konflik dan ketegangan antarkelompok dalam Islam di Indonesia bisa dikatakan sebagai bentuk fundamentalisme Islam.

Fenomena fundamentalisme dan radikalisme di kalangan umat Islam seringkali disandarkan dengan paham keagamaan, sekalipun pencetus radikalisme bisa lahir dari berbagai aspek, seperti ekonomi, politik, sosial dan sebagainya. Radikalisme yang berujung pada terorisme menjadi masalah penting bagi umat Islam Indonesia dewasa ini. Dua isu itu telah menyebabkan Islam dicap sebagai agama teror dan umat Islam dianggap menyukai jalan kekerasan suci untuk menyebarkan agamanya.

\section{B. PEMBAHASAN}

\section{Pengertian Radikalisme Islam}


Seringkali, radikalisme diidentikkan dengan fundamentalisme karena kedua istilah tersebut dalam prakteknya saling terkait. Yang pertama merupakan aksi yang didasarkan pada keyakinan (paham) agama yang tekstualis, sementara yang kedua merupakan pandangan dan sikap beragama yang didasarkan pada ideologi politik Islam sebagai lawan dari politik Barat.

Esposito menjelaskan bahwa sebenarnya istilah radikalisme dan fundamentalisme diterapkan pada spektrum yang luas dari gerakan-gerakan Islam yang pada intinya meliputi orang-orang yang hanya ingin memperkenalkan kembali atau mengembalikan pandangan Islam murni dan puritan dari romantisme masa lalu serta orang-orang yang mendukung reformasi modern yang hanya berakar pada prinsip dan nilai-nilai Islam saja. $^{1}$ Namun demikian, ketika mengacu pada peran Islam dalam politik, fundamentalisme dapat berarti paham ideologi Islam politik atau Islamisme. ${ }^{2}$

Marty dan Appleby, sebagaimana disebut oleh Henry Munson, menyatakan bahwa fundamentalisme merupakan penolakan kaum militan terhadap modernitas sekuler. Mereka berdua menyatakan sebagai berikut:

Fundamentalism is not merely traditional religiosity but rather a religious response to secularization and "modernization." They argue that this response is inherently political, even though the political dimension may be dormant at times. ${ }^{3}$

Meskipun istilah "fundamentalisme" masih menjadi polemik, tetapi karena banyak kasus-kasus radikal dan militansi yang melibatkan agama, maka istilah tersebut tetap dipakai bersamaan dengan istilah radikalisme. Dalam kasus Islam, Henry Munson menyamakan istilah fundamentalisme Islam dengan "islamisme". ${ }^{4}$ Namun demikian, gerakan kaum Islamis (Islamist movements) dapat mengambil banyak bentuk, baik moderat yang menghendaki pembentukan negara Islam tanpa menggunakan kekerasan, maupun militan yang menggunakan kekerasan untuk mencapai tujuannya. ${ }^{5}$

Ada beberapa karakteristik yang bisa dijadikan tanda bagi fundamentalisme Islam. Pertama, kaum fundamentalis bereaksi terhadap marginalisasi agama. Gerakan

\footnotetext{
1 John L. Esposito, What Everyone Needs to Know about Islam: Answers to Frequently Asked Questions from One of America's Leading Experts, edisi ke-2 (Oxford: Oxford University Press, 2002), hlm. 63.

${ }^{2}$ Esposito, What Everyone, hlm. 63.

${ }^{3}$ Henry Munson, "Fundamentalism", Robert A. Segal (ed.), The Blackwell Companion to the Study of Religion (Oxford: Blackwell Pubishing, 2006), hlm. 255.

${ }^{4}$ Ibid., hlm. 265.

${ }^{5}$ Henry Munson, "Fundamentalism", dalam John R. Hinnells, The Routledge Companion to the Study of Religion (New York: Routledge, 2005), hlm. 347.
} 
fundamentalis terbentuk sebagai reaksi terhadap, dan pertahanan terhadap, proses dan konsekuensi sekularisasi dan modernisasi yang telah menembus komunitas agama yang lebih besar. Kedua, kaum fundamentalis menunjukkan moral Manichaean, pandangan dualistik yang tanpa kompromi membagi dunia menjadi dua: cahaya (kebaikan) dan kegelapan (kejahatan). Ketiga, kaum fundamentalis bersikap selektif. Misalnya, mereka menerima banyak ilmu pengetahuan modern dan teknologi modern seperti radio, televisi, komputer, internet, dan sebagainya, tetapi menolak konsep yang timbul dari modernitas seperti demokrasi. Keempat, kaum fundamentalis adalah absolut dan tidak mungkin salah. Mereka secara teguh percaya pada kebenaran mutlak tafsir agama tertentu, tidak terima pada kritik, dan menentang metode hermeneutika yang dikembangkan oleh filosof sekuler. ${ }^{6}$

\section{Akar Radikalisme Islam di Indonesia}

Sejarah radikalisme Islam Indonesia sudah ada sejak dulu. Sejak Kartosuwirjo memimpin operasi 1950-an di bawah bendera Darul Islam (DI). Setelah DI, Komando Jihad (Komji) pada 1976 meledakkan tempat ibadah. Pada 1977, Front Pembebasan Muslim Indonesia melakukan hal sama. Dan tindakan teror oleh Pola Perjuangan Revolusioner Islam, 1978. Radikalisme Islam Indonesia lahir dari hasil persilangan Mesir dan Pakistan. Nama-nama seperti Hassan al-Banna, Sayyid Qutb dan al-Maududi terbukti memengaruhi. Pemikiran mereka membangun cara memahami Islam ala garis keras. Setiap Islam disuarakan, nama mereka semakin melekat dalam ingatan. Bahkan, sampai tahun 1970-1980-an ikut menyemangati perkembangan komunitas usroh di banyak kampus atau organisasi Islam. Juga, FPI dan HTI.

Dalam konteks Indonesia, ada dua hal yang bisa kita baca sebagai penyebab radikalisme. Pertama, warisan sejarah umat Islam yang penuh konflik dengan rezim, karena ada modus-modus penindasan politik Islam yang terjadi pada masa lalu, khususnya Orde Baru. Kelompok yang termarjinalkan secara historis tersebut, dengan kesadaran sejarah, mencoba mengembalikan posisi politik Islam dengan jalan-jalan nonnegara dan struktural. Kedua, fenomena ekonomi-politik. Selain adanya penindasan politik, argumen kedua dari artikel ini adalah adanya penindasan ekonomi-politik. Dengan argumen ini, radikalisme muncul karena ekses kapitalisme yang menciptakan

${ }^{6}$ Gabriel A. Almond, R. Scott Appleby, dan Emmanuel Sivan, Strong Religion: The Rise of Fundamentalisms around the World (Chicago: The University of Chicago Press, 2003), hlm. 93-97. 
mereka yang tak memiliki akses pada sumber-sumber modal. Dalam bahasa ekonomipolitik, pendekatan ini dikenal dengan "pendekatan kelas. Artinya, respons radikalisme pada dasarnya adalah respons kelas untuk melawan hegemoni kapital yang oligarkis dengan negara. ${ }^{7}$

Gerakan Islamis muncul dalam berbagai varian. Ada yang berorentasi politik praktis, ada yang mengedepankan gerakan kultural, Namun keduanya secara tegas membawa ideologi Islam yang pada hakikatnya bertujuan sama yaitu menunjukkan keunggulan (supremasi) dan kebenaran Islam berdasarkan penafsiran mereka sendiri.

Dengan demikian, gerakan fundamentalisme Islam di Indonesia merupakan respon terhadap sesuatu yang dianggap tantangan dari luar Islam dalam upaya mempersempit gerak dan memperlemah agama Islam, antara lain berupa:

1. Tekanan politik dari Negara terhadap kelompok-kelompok Islam yang memperjuangkan penegakan syari'at Islam, bahkan penegakan Negara Islam atau khilāfah. Hal ini juga merupakan upaya Negara dalam mewujudkan sistem pemerintahan yang demokratis;

2. Kondisi sosial yang multikultural dan multi-agama, ${ }^{8}$ yang menyebabkan munculkan konsep pluralisme dan relativisme;

3. Modernisasi yang terjadi di dunia Islam, baik dalam bidang pemikiran keagamaan maupun semua aspek kehidupan sosial, yang sedikit demi sedikit menghilangkan tradisi Islam klasik dan bahkan menghilangkan identitas keislaman (dalam pengertian budaya Arab-Islam).

\section{Ide-Ide Radikalisme Islam di Indonesia}

Fundamentalisme Islam bisa dibedakan antara gerakan budaya dan politik. Sebagai gerakan budaya, fundamentalisme menunjuk sikap anti industrialisme karena dampak sosialnya yang negatif, gerakan budaya ini bisa berubah menjadi gerakan politik yang nampak penuh kekerasan. ${ }^{9}$ Gejala ini terus berubah dinamis akibat

\footnotetext{
7 Ahmad Rizky Mardhatillah Umar, “Melacak Akar Radikalisme Islam di Indonesia”, Jurnal IImu Sosial dan IImu Politik, Volume 14, Nomor 2, November 2010 (169-186), hlm. 172.

${ }^{8}$ Multikulturalisme adalah ide yang dikontestasi dan berkembang tentang bagaimana melihat realitas keragaman masyarakat. Dunia global yang ditandai dengan semakin intensnya proses migrasi dan pertemuan-pertemuan kebudayaan yang berbeda semakin mensignidikasikan konsep multikulturalisme. Kerekatan sosial melalui pemahaman, penghargaan, dan pengakuan atas dasar keadilan sosial dan harga diri manusia adalah idealisme yang ingin dicapai dengan multikulturalisme. Lihat W. Kymlicka, Multicultural Citizenship: A Liberal Theory of Minority Rights (Oxford: Oxford University Press, 1995), dan B. Parekh, Rethinking Multiculturalism: Cultural Diversity and Political Theory (New York: Palgrave Macmillan, 2006).

${ }^{9}$ Kuntowijoyo, Identitas Politik Umat Islam (Bandung: Mizan, 1997), hlm. 36.
} 
perubahan posisi sosial ahli syari'ah yang mulai melakukan penafsiran ulang atas teksteks Islam dan realitas sosial.

Fundamentalisme sebagai gerakan politik bisa dilihat ketika suatu partai dipandang sebagai "partai Tuhan" yang muncul dalam sikap radikal dan doktriner. Di saat lain sikap ini berubah terbuka dan toleran akibat perubahan sosial elite santri. ${ }^{10}$ Perubahan demikian lebih mungkin di tengah perkembangan masyarakat dalam tarikan peradaban global yang semakin kuat.

Fundamentalisme memandang kekuasaan sah jika didasari syari'ah Islam atau didukung oleh elite syari'ah. ${ }^{11}$ Namun gejala ini dapat pula sebagai akibat suatu krisis sosial-ekonomi suatu kelompok masyarakat. Krisis yang menghancurkan hak elite lokal dan keterancaman massa rakyat di bawah eskatologi-mileniaris masa depan ideal yang diyakini akan tiba, memunculkan gerakan revolusioner yang diperkuat dan dilestarikan dengan dalil-dalil syari'ah. ${ }^{12}$

Sikap sosial di atas bisa dikaitkan dengan konsep kekuasaan dalam pandangan kaum fundamentalis yang didasari pada pemahamannya terhadap ajaran Islam bahwa beragama Islam merupakan syarat kewarganegaraan. Konsep ini menempatkan pemeluk lain memiliki hak jika tunduk pada kekuasaan Islam. ${ }^{13}$ Penguasa dipandang sebagai agen (khalīfah) kekuasaan Tuhan yang sah jika dipegang oleh Muslim yang saleh. ${ }^{14}$

Dalam konteks Islam di Indonesia, aspek politik dari fundamentalisme Islam merupakan bentuk perjuangan untuk menerapkan syariat Islam di Indonesia secara formal, meliputi semua bidang hukum, baik perdata maupun pidana. Perjuangan ini pada umumnya dilakukan oleh partai-partai yang berasaskan Islam. Bentuk perjuangan struktural berawal dari terbukanya era reformasi dan demokratisasi setelah runtuhnya rezim Soeharto pada tahun 1998, sehingga upaya mengembalikan teks Piagam Jakarta dalam proses amademen Undang-Undang Dasar 1945 mendapatkan momentumnya. Namun demikian upaya tersebut mengalami kegagalan. Upaya lainnya di bidang struktural adalah dengan cara mengambil jalan lain, yakni berkolaborasi dengan lembaga legislatif dan eksekutif di daerah untuk menerbitkan peraturan daerah (perda) yang bernuansa syariat Islam.

\footnotetext{
${ }^{10}$ Mitsuo Nakamura, Bulan Sabit Muncul dari Balik Pohon Beringin (Yogyakarta: Gadjahmada University Press, 1983 ), hlm. 184.

${ }^{11}$ Abu al-A'lâ Maududi, Hukum dan Konstitusi Sistem Politik Islam (Bandung: Mizan, 1993), hlm. 239.

${ }^{12}$ Sartono Kartodirdjo, Pemberontakan Petani Banten 1888 (Jakarta: Pustaka Jaya, 1984), hlm. 207.

${ }^{13}$ Abdul Muin Salim, Fiqh Siyasah: Konsepsi Kekuasaan Politik dalam Al-Qur'an (Jakarta: Rajagrafindo Persada, 1994), hlm 180-181.

${ }^{14}$ Lihat ibid., hlm. 294.
} 
Sedangkan aspek budaya (kultural) dari fundamentalisme Islam merupakan perjuangan di luar parlemen yang tujuannya juga sama seperti aspek politik, yaitu untuk memformalkan syariat Islam di Indonesia. Fundamentalisme Islam yang bergerak di bidang kultural tersebut diwakili oleh organisasi masyarakat (ormas) Islam seperti Hizbut Tahrir Indonesia (HTI), Front Perjuangan Islam (FPI), Majelis Mujahidin Indonesia (MMI), Kesatuan Mahasiswa Muslim Indonesia (KAMMI), Gerakan Pemuda Islam (GPI), Pelajar Islam Indonesia (PII), Himpunan Mahsiswa Antar Kampus (HAMMAS), Komite Solidaritas Untuk Islam (KISDI), Dewan Dakwah Islamiyah Indonesia (DDII), dan KPPSI (Komite Persiapan Penerapan Syariat Islam) yang berbasis di Sulawesi Selatan. ${ }^{15}$

\section{Isu-Isu yang Dipersoalkan oleh Radikalisme Islam}

\section{Nasionalisme}

Nasionalisme merupakan persoalan yang sangat erat kaitannya dengan nationstate (negara-bangsa) yang tidak hanya mencakup dimensi teritorial tetapi juga hukum dan ideologi. ${ }^{16}$ Karena itulah, masalah nasionalisme di dunia Islam bermula dari adanya fakta terpecahnya umat Islam secara territorial akibat dari kolonialisme Eropa yang berujung pada terbentuknya negara-bangsa dengan batas-batas wilayah dengan kekuasaan yang berbeda-beda.

Terbentuknya konsep negara-bangsa (nation-state) ini setidaknya telah meruntuhkan paradigma kekhalifahan (khilāfah islāmiyah) di mana umat Islam hanya dipimpin oleh seorang khalifah tanpa mengenal batas-batas daerah. Dalam kaitan ini ada dua kelompok utama dalam tubuh umat Islam, yaitu kelompok yang menolak konsep nasionalisme karena dianggap sebagai bentukan Barat yang mengkotak-kotakan umat Islam menjadi kekuatan-kekuatan yang kecil dalam bentuk negara-bangsa yang berbeda-beda, yang bahkan bisa saling berperang satu sama lain.

Kelompok kedua adalah mereka yang menerima konsep nasionalisme, dengan catatan kehidupan syariat Islam berjalan dalam suatu negara. Sedangkan pemikiran Islam yang dikembangkan oleh para pembaharu Muslim pada umumnya membawa semangat yang kurang lebih sama di mana-mana, yaitu pentingnya konteks negara

\footnotetext{
15 Ahmad Syafii Ma'arif, Syariat Islam Yes, Syariat Islam No: Dilema Piagam Jakarta dalam Amandemen UUD 1945 (Jakarta: Paramadina, 2001), hlm. xix.

16 Masykuri Abdillah, Demokrasi di Persimpangan Makna: Respons Intelektual Muslim Indonesia terhadap Konsep Demokrasi (1966-1993) (Yogyakarta: Tiara Wacana, 1999), hlm. 225.
} 
nasional untuk dipertimbangkan dalam memahami ajaran agama. Islam dan negara nasional tidak boleh dipertentangkan. ${ }^{17}$

Kelompok pertama di atas menunjukkan fundamentalisme Islam. Kalangan fundamentalis beranggapan bahwa gagasan tentang negara bangsa (nation-state) yang menimbulkan nasionalisme bertentangan dengan konsep ummah (komunitas Islam) yang tidak mengenal batas-batas politik dan teritorial. Menurut pemahaman mereka, negara Madinah yang dibangun oleh Nabi Muhammad tidak didasarkan pada batas-batas geografis, ras, warna kulit, atau nasionalitas. Negara ini mewakili kehendak bersama dari sebuah masyarakat penganut Islam yang terorgnaisir dan tidak mengenal klan, suku, nasion yang disebut ummah. Ummah yang menegakkan negara ini pada hakekatnya bersifat supra nasional dan satu-satunya kekuatan pemersatu umat manusia yang berbeda-beda di dalam tradisi, adat kebiasaan, ras, dan nasionalitas adalah wahyu. ${ }^{18}$

\section{Demokrasi}

Secara literal demokrasi berarti kekuasaan oleh rakyat. Secara historis istilah demokrasi telah dikenal sejak abad ke-5 SM, yang pada awalnya sebagai respons terhadap pengalaman buruk monarki dan kediktatoran di negara-negara kota Yunani kuno. Ide demokrasi modern berkembang pada abad ke-16 M. ${ }^{19}$

Di masa kontemporer sekarang ini, istilah demokrasi bagi banyak orang dianggap sebagai kata yang mengimplikasikan nilai-nilai perjuangan untuk kebebasan dan jalan hidup yang lebih baik. ${ }^{20}$ Demokrasi bukan hanya merupakan metode kekuasaan mayoritas melalui partisipasi rakyat dan kompetisi yang bebas, tetapi juga mengandung nilai-nilai universal, khususnya nilai-nilai persamaan, kebebasan dan pluralisme, walaupun konsep-konsep operasionalnya bervariasi menurut kondisi budaya negara tertentu. Nilai demokrasi juga berkaitan dengan eksistensi dan pemeliharaan hak asasi manusia (HAM) ${ }^{21}$

Banyak umat Islam yang menerima konsep demokrasi sebagai sebuah sistem negara, dalam arti bagaimana seorang pemimpin negara dipilih. Secara teologis

\footnotetext{
17 Ulil Abshar Abdalla, "Memikirkan Agenda Pembaharuan Islam ke Depan”, makalah untuk Studium Generale yang diadakan oleh Fahmina Institute, Cirebon, pada Minggu 3 Oktober 2010, hlm.5.

${ }^{18}$ Qamaruddin Khan, Pemikiran Politik Ibnu Taymiyah (Bandung: Pustaka, 1995), h. 172.

${ }^{19}$ Abdillah, Demokrasi, hlm. 71.

${ }^{20}$ Ibid., hlm. 74.

${ }^{21} \mathrm{lbid}$.
} 
penerimaan para intelektual Muslim terhadap demokrasi didasarkan pada ayat-ayat al-Qur'an dan praktek historis masa Nabi Muhammad SAW dan al-khulafa' alrasyidun. Ayat al-Qur'an yang biasa dijadikan dasar untuk mendukung sistem negara demokrasi antara lain QS. 3: 159 "wa syāwirhum fil-amr”, QS. 42: 38 "wa amruhum syūrā baynahum". Meskipun pemimpin dipilih oleh rakyat, tetapi sebagian besar umat Islam masih mengakui kedaulatan Tuhan, dalam arti suara mayoritas tidak dapat atau tidak mungkin mengubah syari'ah. Sedangkan sebagian kecil umat Islam menerima kedaulatan rakyat dalam pengertian prkatis. ${ }^{22}$

Dengan demikian, sebenarnya umat Islam memiliki konsep sendiri tentang demokrasi, karena jika dihadapkan pada konsep demokrasi yang memuat nilai-nilai standar dari konsep demokrasi itu sendiri, mereka masih memiliki sikap yang berbeda-beda. Nilai-nilai demokrasi yang dimaksud, sebagaimana telah disebutkan di atas, adalah persamaan (termasuk kesetaraan gender), kebebasan (termasuk kebebasan beragama, yang dimaknai juga sebagai kebebasan untuk tidak beragama), dan pluralisme. Nilai-nilai demokrasi tersebut di dunia Islam masih menjadi isu yang kontroversial, sebagian umat Islam menerima, sebagian lagi menolaknya.

\section{Hak Asasi Manusia}

Salah satu asas demokrasi yang terpenting adalah bahwa demokrasi harus berdasar pada asas kedaulatan rakyat dan penghormatan hak-hak asasi manusia $(\mathrm{HAM}){ }^{23}$ Munculnya Deklarasi Universal tentang Hak-hak Asasi Manusia (DUHAM), yang didasarkan pada pertimbangan kemanusiaan semata, telah menjadikan problem kemanusiaan yang selama bertahun-tahun berada di bawah kungkungan dogma agama harus dilepaskan dari nilai-nilai agama. DUHAM menuntut manusia seluruh dunia untuk meletakkan nilai kemanusiaan (hak-hak asasi manusia) di atas nilai-nilai agama dan tidak dapat dibenarkan menghilangkan nilai kemanusiaan demi membela agama apa pun. ${ }^{24}$

Bagi sebagian umat Islam, yang menganggap hak asasi manusia sebenarnya sudah lama diatur dalam Islam, maka yang harus dilakukan saat ini adalah

\footnotetext{
22 lbid., hlm. 77.

23 Aswab Mahasin, "Agama dan Demokrasi : Bukan Pohon Tanpa Akar", dalam M. Imam Aziz, dkk., Agama, Demokrasi, dan Keadilan (Jakarta: Gramedia, 1993), hlm. 30-31.

${ }^{24}$ Adang Djumhur Salikin, Reformasi Syari'ah dan HAM dalam Islam: Bacaan Kritis Terhadap Pemikiran An-Naim (Yogyakarta: Gama Media, 2004), hlm. 1.
} 
bagaimana menemukan rujukan teologis bagi persoalan tersebut. Namun demikian, sebagian umat Islam yang lain melakukan penolakan terhadap DUHAM, karena melihat adanya perbedaan kebudayaan yang melahirkan hak asasi manusia tersebut. Pendekatan hak asasi manusia dalam Islam memiliki nilai yang khas berupa nilai yang datang dari wahyu, dan ini berbeda dengan universalitas HAM yang notabene datang dari Barat. ${ }^{25}$

Isu-isu HAM yang menjadi perdebatan di kalangan umat Islam antara lain adalah: hukuman dalam jinayah (qisas, rajam, dan potong tangan), kebebasan beragama (termasuk kebebasan berpindah agama dari Islam ke non-Islam dan juga kebebasan untuk tidak beragama), perlakuan yang sama secara sosial dan politik untuk semua warga negara tanpa membedakan suku, agama, ras dan golongan (dalam fiqih siyasah Islam membedakan warga negara menjadi Muslim dan żimmy, di mana warga negara non-Muslim/żimmy tidak memiliki hak yang sama dengan Muslim), dan isu-isu kesetaraan gender.

Islam pada kenyataannya memberikan kemungkinan pada bermacam interpretasi; Islam bisa digunakan untuk mendukung demokrasi maupun kediktatoran; republikanisme maupun monarki. Menurut John L. Esposito, reaksi negatif umat Islam terhadap demokrasi Barat seringkali merupakan bagian dari penolakan umum terhadap pengaruh kolonial Eropa, daripada suatu penolakan umum pada demokrasi. ${ }^{26}$

\section{Upaya Melawan Radikalisme Islam}

\section{Tajdid dan Ijtihad}

Meskipun pembaruan pemikiran modern dalam Islam seringkali ditampilkan sebagai respon terhadap tantangan dari dunia Barat, tetapi sebenarnya pemikiran tersebut mempunyai akar dalam tradisi Islam sendiri. Islam memiliki tradisi yang panjang dalam hal tajdid (pembaruan) dan ijtihad (reformasi). ${ }^{27}$ Karena itulah, umat Islam yang berusaha melakukan penyesuaian ajaran Islam dengan nilai-nilai modern biasa menggunakan konsep tajdid dan ijtihad tersebut. Kedua konsep tersebut menjadi

\footnotetext{
25 Ibid.

${ }^{26}$ John L. Esposito (ed.), The Oxford History of Islam (Oxford: Oxford University Press, 1999), hlm. 676.

${ }^{27}$ Tauseef Ahmad Parray, "Islamic Modernist and Reformist Thought: A Study of the Contribution of Sir Sayyid and Muhammad Iqbal", World Journal of Islamic History and Civilization, Vol. 1, No. 2, tahun 2011, hlm. 82.
} 
pilihan yang dimanfaatkan secara maksimal oleh umat Islam untuk menjaga dan melestarikan ajaran Islam agar sesuai dengan kondisi kehidupan modern.

Tajdid berarti pembaruan, yakni pembaruan pemahaman terhadap segenap aspek ajaran Islam agar bisa menjawab tantangan zaman. Jalan menuju tajdid disebut ijtihad. Dengan demikian tajdid dan ijtihad adalah satu paket yang biasa dilakukan oleh umat Islam dalam menghadapi problem kehidupan di setiap tempat dan zaman. Khazanah keilmuan Islam klasik/abad pertengahan sebagaimana yang sudah dikenal hingga sekarang ini tidaklah cukup memadai untuk menghadapi persoalan dan tantangantantangan baru era modernitas dan pasca-modernitas. Untuk keluar dari paradigma keilmuan agama Islam yang lama ke yang baru perlu upaya-upaya baru yang dapat mengawinkan, memperkaya, mempertautkan khazanah intelektual lama (al-turāis) dengan khazanah intelektual baru (al-ḥadāisah; bahkan mā ba'da al-ḥadāisah) agar generasi baru yang hidup pada era global sekarang dan lebih-lebih yang akan datang tidak gamang menghadapi modernitas dan pasca-modernitas.

\section{Al-Qirā'ah al-Muntijah (Pembacaan yang Produktif)}

Upaya memahami isu-isu global harus selalu berada dalam orbit kultur akademik yang terukur secara ilmiah dengan metodologi yang jelas, sehingga persoalan-persoalan yang dibahas dalam perkuliahan ini dapat terhindar dari adanya klaim-klaim kebenaran (truth claim) yang justru dapat membawa pada situasi yang bertentangan dengan tradisi akademik yang baik.

Sejatinya, kajian isu-isu global kontemporer dapat memberikan kontribusi gagasan-gagasan besar ilmiah yang memicu gerakan intelektual dalam peradaban dunia modern. Lahirnya daya kritis berkat adanya kajian-kajian ilmiah dengan paradigma keilmuan yang jelas. Dengan cara berfikir kritis, para intelektual mengetahui problem dunia yang sedang dihadapi sembari mengusulkan pelbagai pemecahan yang harus segera dilakukan. Dalam dunia Islam khususnya, cara pandang para pemeluknya masih berkutat pada isu-isu internal umat Islam sendiri yang bahkan belum terselesaikan. Hal ini disebabkan karena umat Islam selalu menggunakan cara pandang yang sama (alqirā'ah al-mutakarrirah) dalam melihat perubahan. Akibatnya, dunia Islam tidak pernah melangkah jauh dan tidak pernah berkembang.

Agar umat Islam tidak tertinggal oleh gerbong peradaban dunia global sekarang ini, perlu dilakukan upaya-upaya yang sistematis dalam hal pembaharuan pemikiran dan 
rekonsturksi epistemologi studi Islam dalam rangka penafsiran ulang (reinterpretasi) ajaran agama. Banyak ulama-ulama kontemporer yang sudah melakukan upaya pembacaan ulang atas teks-teks ajaran agama (al-Qur'an dan Sunnah) tersebut. Nasr Hamid Abu Zayd, misalnya, mencoba menawarkan teori teks dalam hermeneutik dengan teorinya yang menyatakan bahwa al-Qur'an betapapun mempunyai nilai sakralitas karena merupakan wahyu Allah, tetapi ia merupakan teks yang juga dapat dikaji secara kritis seperti teks-teks lainnya. ${ }^{28}$ Sementara itu, Arkoun juga mencoba menawarkan metode baru bagaimana mengkaji al-Qur'an secara lebih kritis. Menurutnya al-Qur'an merupakan teks yang selalu terbuka (korpus terbuka) untuk ditafsirkan, sehingga jangan sampai ada taqdi>s al-afka>r al-di>niyyah atau pensakralan pemikiran keagamaan, termasuk dalam penafsiran al-Qur'an. ${ }^{29}$

Dengan demikian, apa yang sudah dilakukan oleh para ulama kontemporer seperti Abu Zayd dan Arkoun merupakan suatu upaya melakukan reinterpretasi alQur'an melalui pembacaan atas teks-teks wahyu secara produktif (al-qira>'ah almuntijah). Al-qira>'ah al-muntijah (pembacaan yang produktif) merupakan cara pembacaan teks-teks ajaran Islam dengan mempertimbangkan pemahaman seseorang terhadap perubahan-perubahan sejarah, sehingga pembacaan yang produktif akan selalu mempertimbangkan aspek historisitas (ta>rikhiyyah), dan yang dimaksud dengan historisitas tersebut adalah adanya dimensi perubahan (sosial, politik, ekonomi, budaya) dalam sebuah masyarakat.

\section{Kesadaran akan Multikulturalisme}

Multikulturalisme adalah ide yang terkait dengan dunia global yang ditandai dengan semakin intensnya proses migrasi dan pertemuan-pertemuan kebudayaan yang berbeda. Kerekatan sosial melalui pemahaman, penghargaan, dan pengakuan atas dasar keadilan sosial dan harga diri manusia adalah idealisme yang ingin dicapai dengan multikulturalisme. ${ }^{30}$

Pendidikan dan lembaga pendidikan sangat berpeluang menjadi penyebar benih radikalisme dan sekaligus penangkal (baca: deradikalisasi) Islam radikal. Studi-studi tentang radikalisme dan terorisme mensinyalir adanya lembaga pendidikan Islam tertentu (terutama yang nonformal, seperti pesantren) telah mengajarkan

\footnotetext{
${ }^{28}$ Nasr Hamid Abu Zayd, Naqd al-Khitab al-Dīnī, cet. 4 (Kairo, Madbuli, 2003).

${ }^{29}$ Mohammed Arkoun, Rethinking Islam: Common Questions, Uncommon Answers (London: Routledge, 1994).

${ }^{30}$ B. Parekh, Rethinking Multiculturalism: Cultural Diversity and Political Theory (New York: Palgrave Macmillan, 2006).
} 
fundamentalisme dan radikalisme kepada para peserta didik. Belakangan, sekolahsekolah formal juga mulai mengajarkan elemen-elemen Islam radikal, misalnya mengajarkan kepada murid untuk tidak menghormat bendera Merah Putih saat upacara bendera. ${ }^{31}$ Untuk mencegah penyebaran ideologi Islam radikal, deradikalisasi merupakan suatu keharusan dan mesti dilakukan dengan berbagai strategi di berbagai tempat. Pendidikan sebagai pusat pembelajaran adalah tempat strategis untuk menanamkan paham Islam moderat.

\section{Perlunya Kesadaran Muslim sebagai Bagian dari World Citizenship}

Perubahan sosial yang cepat di masa sekarang merupakan implikasi dan konsekwensi dari globalisasi dunia yang diakibatkan oleh kemajuan ilmu penetahuan dan teknologi. Globalisasi telah menyebabkan umat Islam yang hidup saat sekarang ini di manapun mereka berada sebagai bagian dari warga dunia (world citizenship), selain sebagai warga lokal/nasional, yang tidak dapat lepas dari pengaruh dan bahkan pengamatan global warga dunia yang lain. Perubahan sosial yang begitu cepat tersebut berdampak luar biasa dan mengubah pola berpikir dan pandangan keagamaan (religious worldview) yang berbeda di lingkungan umat Islam dibanding masa-masa sebelumnya.

Masyarakat Muslim kontemporer di manapun berada, sekarang terikat dengan kesepakatan dan perjanjian-perjanjian internasional, oleh karena itu umat Islam harus memiliki pemahaman dan kesadaran tentang pentingnya harkat dan martabat manusia (human dignity), dan perlu lebih sering melakukan perjumpaan yang lebih dekat antarumat beragama (greater inter-faith interaction). ${ }^{32}$ Minimnya perlindungan HAM dan masih diberlakukannya pelaksanaan hukuman-hukuman yang kejam (yang terdapat dalam al-fiqh al-jina $>y a>t$ ) oleh negara-negara Muslim selalu mendapat perhatian dari dunia internasional karena dianggap tidak sesuai dengan nilai-nilai universal tersebut. Karena itulah, umat Islam harus dapat berkomunikasi secara global-universal disertai dengan adaptasi terhadap nilai-nilai universal yang telah disepakati dunia internasional.

\section{SIMPULAN}

\footnotetext{
31 M. Amin Abdullah, "Islamic Studies in Higher Education in Indonesia", Al-Jami'ah: Journal of Islamic Studies, Vol. 55, No. 2, 2017: 391-426.

32 M. Amin Abdullah, "Bangunan Baru Epistemologi Keilmuan Studi Islam dalam Merespon Globalisasi", Asy-Syir'ah: Jurnal IImu Syari'ah dan Hukum, Vol. 46, No. 2, Juli-Desember 2012: 315-368.
} 
Selama beberapa dekade terakhir, fenomena kekerasan yang mengatasnamakan agama meningkat dan terasa cukup mengganggu kedamaian yang sudah sekian lama tercipta di Indonesia. peningkatan konstelasi kekerasan ini menimbulkan tanda tanya tentang sikap keberagamaan sebagian umat Islam Indonesia yang meyakini bahwa agama mereka merupakan agama pemberi rahmat, dan juga kondisi ini mempertanyakan sikap mereka terhadap kemajemukan bangsa atau multikulturalisme, serta terhadap demokrasi dan modernisasi.

Sikap penolakan terhadap hal-hal baru yang berasal dari luar Islam seringkali dikaitkan dengan isu fundamentalisme dan radikalisme dalam Islam. Tuduhan terhadap Islam yang tidak hanya membawa misi perdamaian, tetapi juga misi kekerasan sulit untuk ditolak manakala kita menyaksikan bahwa agama seringkali digunakan sebagai landasan ideologis dan pembenaran simbolis bagi tindak kekerasan yang dilakukan sebagian umatnya. Fundamentalisme Islam di Indonesia ada yang berorientasi politik praktis, ada yang mengedepankan gerakan kultural, namun keduanya secara jelas membawa ideologi Islam yang pada hakekatnya bertujuan sama, yaitu menunjukkan keunggulan (supremasi) dan kebenaran Islam berdasarkan penafsiran mereka sendiri.

Upaya melawan readikalisme/fundamentalisme Islam adalah dengan bersuara menyampaikan gagasan Islam yang toleran dan inklusif, serta dengan melakukan reinterpretasi ajaran Islam, yakni tajdid dan ijtihad. Selain itu radikalisme juga harus dilawan melalui dunia pendidikan yang menekankan aspek-aspek kesadaran multikultural dan kesadaran umat Islam sebagai bagian dari world citizenship.

\section{DAFTAR PUSTAKA}

Abdalla, Ulil Abshar. "Memikirkan Agenda Pembaharuan Islam ke Depan", makalah untuk Studium Generale yang diadakan oleh Fahmina Institute, Cirebon, pada Minggu 3 Oktober 2010.

Abdillah, Masykuri. Demokrasi di Persimpangan Makna: Respons Intelektual Muslim Indonesia terhadap Konsep Demokrasi (1966-1993). Yogyakarta: Tiara Wacana, 1999.

Abdullah, M. Amin. "Bangunan Baru Epistemologi Keilmuan Studi Islam dalam Merespon Globalisasi”, Asy-Syir'ah: Jurnal Ilmu Syari'ah dan Hukum, Vol. 46, No. 2, Juli-Desember 2012: 315-368.

Abdullah, M. Amin. "Islamic Studies in Higher Education in Indonesia", Al-Jami'ah: Journal of Islamic Studies, Vol. 55, No. 2, 2017: 391-426.

Abu Zayd, Nasr Hamid. Naqd al-Khitab al-Dīn̄, cet. 4. Kairo, Madbuli, 2003. 
Almond, Gabriel A., R. Scott Appleby, dan Emmanuel Sivan, Strong Religion: The Rise of Fundamentalisms around the World. Chicago: The University of Chicago Press, 2003.

Arkoun, Mohammed. Rethinking Islam: Common Questions, Uncommon Answers. London: Routledge, 1994.

Esposito, John L. (ed.). The Oxford History of Islam (Oxford: Oxford University Press, 1999), hlm. 676.

Esposito, John L. What Everyone Needs to Know about Islam: Answers to Frequently Asked Questions from One of America's Leading Experts, edisi ke-2. Oxford: Oxford University Press, 2002.

Kartodirdjo, Sartono. Pemberontakan Petani Banten 1888. Jakarta: Pustaka Jaya, 1984.

Khan, Qamaruddin. Pemikiran Politik Ibnu Taymiyah. Bandung: Pustaka, 1995.

Kuntowijoyo, Identitas Politik Umat Islam. Bandung: Mizan, 1997.

Kymlicka, W. Multicultural Citizenship: A Liberal Theory of Minority Rights. Oxford: Oxford University Press, 1995.

Ma'arif, Ahmad Syafii. Syariat Islam Yes, Syariat Islam No: Dilema Piagam Jakarta dalam Amandemen UUD 1945. Jakarta: Paramadina, 2001.

Mahasin, Aswab. "Agama dan Demokrasi : Bukan Pohon Tanpa Akar", dalam M. Imam Aziz, dkk., Agama, Demokrasi, dan Keadilan. Jakarta: Gramedia, 1993.

Maududi, Abu al-A'lâ. Hukum dan Konstitusi Sistem Politik Islam. Bandung: Mizan, 1993.

Munson, Henry. "Fundamentalism", dalam John R. Hinnells (ed.), The Routledge Companion to the Study of Religion. New York: Routledge, 2005.

Munson, Henry. "Fundamentalism", Robert A. Segal (ed.), The Blackwell Companion to the Study of Religion. Oxford: Blackwell Pubishing, 2006.

Nakamura, Mitsuo. Bulan Sabit Muncul dari Balik Pohon Beringin. Yogyakarta: Gadjahmada University Press, 1983.

Parekh, B. Rethinking Multiculturalism: Cultural Diversity and Political Theory. New York: Palgrave Macmillan, 2006.

Parray, Tauseef Ahmad. "Islamic Modernist and Reformist Thought: A Study of the Contribution of Sir Sayyid and Muhammad Iqbal", World Journal of Islamic History and Civilization, Vol. 1, No. 2, tahun 2011.

Salikin, Adang Djumhur. Reformasi Syari'ah dan HAM dalam Islam: Bacaan Kritis Terhadap Pemikiran An-Naim. Yogyakarta: Gama Media, 2004.

Salim, Abdul Muin. Fiqh Siyasah: Konsepsi Kekuasaan Politik dalam Al-Qur'an. Jakarta: Rajagrafindo Persada, 1994.

Umar, Ahmad Rizky Mardhatillah. "Melacak Akar Radikalisme Islam di Indonesia", Jurnal Ilmu Sosial dan Ilmu Politik, Volume 14, Nomor 2, November 2010 (169186). 